\title{
Promoting progression and clinicopathological significance of NEAT1 over-expression in bladder cancer
}

\author{
Chen XianGuo ${ }^{1}$, Hao ZongYao ${ }^{1}$, Zhou Jun ${ }^{1}$, Fan Song ${ }^{1}$, Luo GuangYue ${ }^{1}$, Zhang \\ LiGang ${ }^{1}$, Zhang KaiPing ${ }^{1}$, Zhang YangYang ${ }^{1}$, Liang ChaoZhao ${ }^{1}$ \\ ${ }^{1}$ Department of Urology, The First Affiliated Hospital of Anhui Medical University, Hefei, Anhui 230022, PR China \\ Correspondence to: Liang ChaoZhao, email: liang_chaozhao@163.com \\ Keywords: NEAT1, bladder cancer, long noncoding RNA, clinical pathologic \\ Received: November 07, $2015 \quad$ Accepted: May 28, $2016 \quad$ Published: June 15, 2016
}

\section{ABSTRACT}

Bladder cancer was the most important reason of cancer-related death around the world, and urgently requires new therapeutic methods targeting the malignant tumor. There are many reports that the long noncoding RNAs are participated in different cancers, however, limited data are found between the long noncoding RNAs and bladder cancer. Previous studies have indicated that IncRNAs play vital roles in gene regulatory processes which could influence carcinoma progression.It is well known that IncRNAs can't code proteins, however, controlling transcription was found in the life process.In the current study, we firstly reported that NEAT1 was consistently up-regulated in bladder cancer tissues compared to the matched tissues and bladder cancer cell lines compared to the normal bladder epithelial cell and the expression level of the NEAT1 in bladder cancer tissues is closely related to its clinical pathologic grade and TNM phase. Cell proliferation inhibition, cell migration suppression and apoptosis induction were detected by knockdown NEAT1. However, it is imperative that this hypothesis is further tested through. In conclusion, NEAT1 may play oncogenic roles and can be used as a therapeutic target for treating human bladder cancer. Our finding provides a new insight into the role of the LncRNA NEAT1 in the bladder cancer.

\section{INTRODUCTION}

According to recent study, bladder cancer is still the primary reason of cancer death in the human diseases, especially in the advanced cancer patients. Even though the diagnosis and therapy have been made great progress $[1,2]$, bladder cancer remains a seriously lethal disease because people easily neglect it until advanced stage. In addition, many bladder cancer patients are f recurred easily after the surgery [3] and eventual resistance to chemotherapy and radiotherapy in the subsequent treatment. This highlights the imminent requirement for discovering more molecular markers that can be potential and efficacious therapeutic targets [4].

Long noncoding RNAs (LncRNAs), Length is than the $200 \mathrm{~kb}$, and has been continually reported to be involved in tumorigenesis and developing [5-10]. LncRNAs play potential onco- or tumor-suppressor roles [11-17]. LncRNAs abnormal expression was reported in the carcinomas, including PVT1 [18] and UCA1 ect. We supposed that NEAT1(nuclear paraspeckle assembly transcript 1) should affect that through a similar way. NEAT1 were reported high regulation in various kinds of diseases [19-28]. MiR-140, HIF-2 $\alpha$, miR-449b-5p/c-Met axis and MicroRNA-449a have been tested in the relation with the high expression of the NEAT1 from the previous studies. However, there is no study the role of NEAT1 in bladder cancer. Inspired by these outstanding research results, we proposed the hypothesis that the NEAT1 could play a similar role in bladder cancer. However, it is imperative that this hypothesis is further tested through.

In this survey, NEAT1 was firstly found to be upregulated in bladder cancer tissues and cell lines. Inhibited bladder cancer cell growth, suppressed migration and induced apoptosis were detected by silencing NEAT1, as consistent as previous literature reported and our assumption. We suggested that the NEAT1 acted as bladder cancer oncogene, and it could provide a new approach to cure bladder cancer. 


\section{RESULTS}

\section{NEAT1 was high expression in bladder cancer and cell lines}

NEAT1 was high expression obviously in $73.8 \%$ (48 of 65) $(\mathrm{P}=0.0022)$ (Figure 1A and 1B) in tissues. NEAT1 was increased obviously in $5637(\mathrm{P}=0.0047)$, T24 $(\mathrm{P}=$ $0.0036)$ and SW780 $(\mathrm{P}<0.001)$, compared with the SVHUC-1, (Figure 1C-1E). Overexpression of NEAT1 was closely related to histological grade, tumor invasion depth and TNM stage $(\mathrm{P}<0.01)$ (Table 1). But there is no relation with gender, age and size etc.

\section{Silencing NEAT1 arrested cell proliferation}

At 48 hours after transfection of si-NEAT1, siNEAT1(a) and si-NC in 5637, T24 and SW780 cell lines, qRT-PCR detected the related NEAT1 expression level. Compared the related expression level of NEAT1 after si-NEAT1(a) transfection being $5637(\mathrm{p}$ $=0.02186), \mathrm{T} 24(\mathrm{P}=0.0278)$ and $\mathrm{SW} 780(\mathrm{P}=0.01625)$, the related expression level of NEAT1 after si-NEAT1 transfection were $5637(\mathrm{p}=0.00573), \mathrm{T} 24(\mathrm{P}=0.00072)$ and $\mathrm{SW780}(\mathrm{P}=0.00066)$ (Figure 2A-2C). As a result, we determined to choose the more effective sequences of siNEAT1 for further experiment. MTT assay was detected that si-NEAT1 remarkably inhibited the proliferation of three bladder cancer cells $(\mathrm{p}<0.001)$ (Figure 2D-2F).
Cell growth was detected EdU assay. Compared to EdU positive in si-NC group, EdU positive in si-NEAT1 group were decreased (Figure 3A-3C). The quantity of EdU positive cells was significantly reduced in 5637 $(\mathrm{P}=0.00769), \mathrm{T} 24(\mathrm{P}=0.00620)$ and $\mathrm{SW} 780(\mathrm{P}=0.00367)$ in si-NEAT1 group (Figure 3D-3F).

\section{Silencing NEAT1 suppressed cell migration}

Cell migration was detect the role of specific siRNA in the cell scratch assay. Cells were seeded after transfection with si-NEAT1 or si-NC. Compared with the control group, cell migration was remarkably suppressed, 5637 cell $(\mathrm{P}=0.00222), \mathrm{T} 24(\mathrm{P}=0.03203)$ and $\mathrm{SW780}(\mathrm{P}=0.02957)$ in si-NEAT1 goup (Figures $4 \mathrm{~A}-4 \mathrm{~F})$. These results implied that NEAT1 promoted bladder cancer cell migration.

\section{Silencing NEAT1 induced apoptosis}

Cells were transfected with siRNA. $48 \mathrm{~h}$ after transfection, ELISA assay determined the relative caspase-3 activity, 5637 cell $(\mathrm{P}=0.00030), \quad \mathrm{T} 24$ $(\mathrm{P}=0.00134)$ and $\mathrm{SW} 780(\mathrm{P}<0.001)$ (Figures $5 \mathrm{~A}-5 \mathrm{C})$ and the flow cytometry analysis measured the bladder cancer cells apoptosis ratio (Figures 5D-5F). Cell apoptosis was observed in 5637,T24 and SW780. These results manifested that NEAT1 suppressed bladder cancer cell apoptosis.
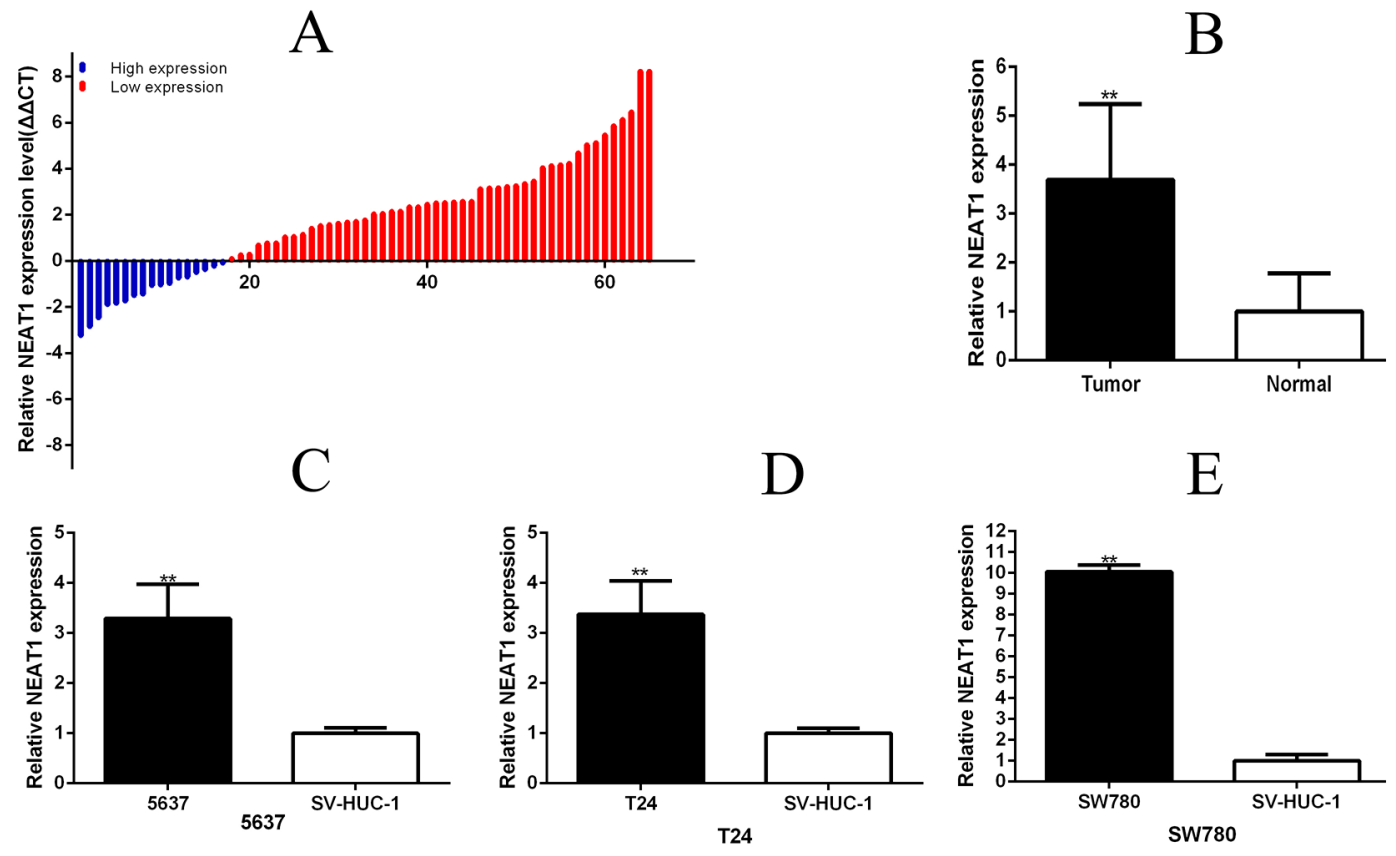

Figure 1: NEAT1 was up-regulated in bladder cancer tissues and cell lines. Relative NEAT1 concentration was detected using Real-Time qPCR. NEAT1 expression levels were higher in bladder cancer tissues than those in normal bladder tissues $\mathbf{A}$ and $\mathbf{B}$. (p $<0.01)$, and 5637\T24\SW780 cancer cell lines than the normal bladder epithelial cell (SU-HUC-1) C, D and E. (p<0.01). Data are shown as mean $\pm \mathrm{SD}(* * \mathrm{p}<0.01)$. 
Table 1: Correlation between NEAT1 expression and clinicopathological characteristics of bladder cancer patients

\begin{tabular}{|c|c|c|c|c|}
\hline \multirow[t]{2}{*}{ Characteristics } & \multirow[t]{2}{*}{ Total } & \multicolumn{2}{|c|}{ Expression of NEAT1 } & \multirow[t]{2}{*}{$P$ value } \\
\hline & & $\begin{array}{c}\text { High } \\
(n=48)\end{array}$ & $\begin{array}{c}\text { Low } \\
(n=17)\end{array}$ & \\
\hline \multicolumn{5}{|l|}{ Gender } \\
\hline Male & 49 & $37(75.5 \%)$ & $12(24.5 \%)$ & 0.744 \\
\hline Female & 16 & $11(68.8 \%)$ & $5(31.2 \%)$ & \\
\hline \multicolumn{5}{|l|}{ Age } \\
\hline$\leq 60$ & 29 & $19(65.5 \%)$ & $10(34.5 \%)$ & 0.256 \\
\hline$>60$ & 36 & $29(80.6 \%)$ & $7(19.4 \%)$ & \\
\hline \multicolumn{5}{|l|}{ Tumor size $(\mathrm{cm})$} \\
\hline$<3 \mathrm{~cm}$ & 30 & $21(70.0 \%)$ & $9(30.0 \%)$ & 0.579 \\
\hline$\geq 3 \mathrm{~cm}$ & 35 & $27(77.1 \%)$ & $8(22.9 \%)$ & \\
\hline \multicolumn{5}{|l|}{ Histological grade } \\
\hline PUNLMP/Low-grade & 24 & $13(54.2 \%)$ & $11(45.8 \%)$ & $0.009 * *$ \\
\hline High-grade & 41 & $35(85.4 \%)$ & $6(14.6 \%)$ & \\
\hline \multicolumn{5}{|c|}{ Tumor invasion depth (T) } \\
\hline Tis, Ta, T1 & 30 & $15(50.0 \%)$ & $15(50.0 \%)$ & $<0.001^{* *}$ \\
\hline $\mathrm{T} 2, \mathrm{~T} 3$ or above & 35 & $33(94.3 \%)$ & $2(5.70 \%)$ & \\
\hline \multicolumn{5}{|c|}{ Lymph node metastasis(N) } \\
\hline N0 & 62 & $45(93.8 \%)$ & $17(6.20 \%)$ & 0.561 \\
\hline N1 or above & 3 & $3(100 \%)$ & $0(0.00 \%)$ & \\
\hline \multicolumn{5}{|l|}{ TNM stage } \\
\hline $0 / \mathrm{I}$ & 28 & $13(46.4 \%)$ & $15(53.6 \%)$ & $<0.001 * *$ \\
\hline II/III/IV & 37 & $35(94.6 \%)$ & $2(5.40 \%)$ & \\
\hline
\end{tabular}

\section{DISCUSSION}

Malignant bladder cancer is rather difficult to cure with current therapies especially the advanced cancer [1-3]. LncRNAs do not code proteins and couid be participate in the life control [29-31]. Recently, lncRNAs were found to involve in cancer progression [32-34]. LncRNAs could have carcinogenesis and antitumor effect, which indicates that lncRNAs may be valuable biomarkers and therapeutic targets [35-38].

MiR-140, HIF-2 $\alpha$, miR-449b-5p/c-Met axis and MicroRNA-449a have been tested in the relation with the high expression of the NEAT1 from the previous studies and so on $[22,24,25,39-46]$. These findings provide the first large-scale survey of lncRNAs associated with the development of carcinogenesis and may offer new diagnostic biomarkers and therapeutic targets for malignancy. Based on the prior studies, we can draw the conclusion that LncRNA NEAT1 play roles in a wide range that the reason we choose it as our study target in the bladder cancer.
So far, the role of NEAT1 was first reported in bladder cancer. Significantly higher NEAT1 expression was found in bladder cancer tissues. Furthermore, the relationship between NEAT1 expression and hepatocellular carcinoma or lung cancer patients clinicopathological parameters were found in the previous study [12-13].In this study, its similar trend was detected in the bladder cancer tissues that's highly related to clinicopathological parameters. To study NEAT1 in bladder cancer, bladder cancer cell proliferation, migration and apoptosis were detected by silencing NEAT1. Compared to the control group, inhibited proliferation, suppressed migration and increased apoptosis were remarkably shown in si-NEAT1transfected bladder cells. These results made clear that the NEAT1 may play in the bladder cancer progression and deterioration $[47,48]$. Further studies in vivo are to explore the NEAT1 mechanism in bladder cancer in the future. In a word, lncRNA NEAT1 may act as an oncogene in bladder cancer, which plays an important role in the tumorigenesis and deterioration. It could potentially serve 

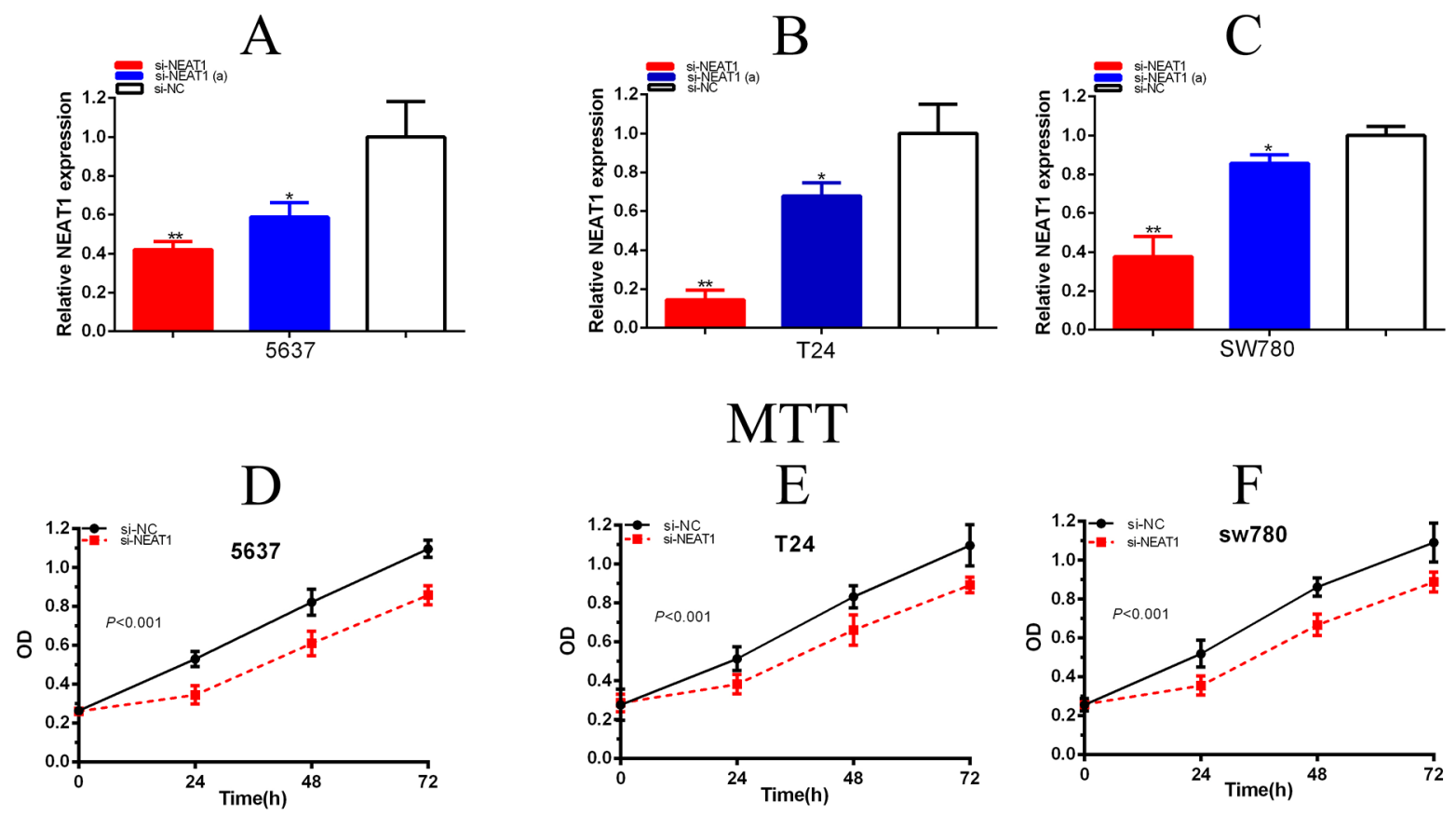

Figure 2: Expression changes of NEAT1 after transfection and silencing NEAT1 inhibited cell proliferation by MTTassay. The relative expression level was evaluated using real-time qPCR. The si-NEAT1 was more significantly down-regulated the expression level of NEAT1 than the si-NEAT1 in 5637 A. T24 B. and SW780 C. cells (p<0.01). Cell proliferation was detected by MTT-assay. After transfection of si-NEAT1 or negative control si-NC, OD values were measured. ANOVA was used for the comparison of curves of cell proliferation. Cell proliferation inhibition was observed in bladder cancer 5637 cells (A), T24 cells (B), and SW780 cells (C) (p<0.01). Each experiment in three cell lines was performed in triplicate for three independent times. Data are indicated as mean $\pm \operatorname{SD}(* \mathrm{P}<0.05$, $* * \mathrm{p}<0.01)$.

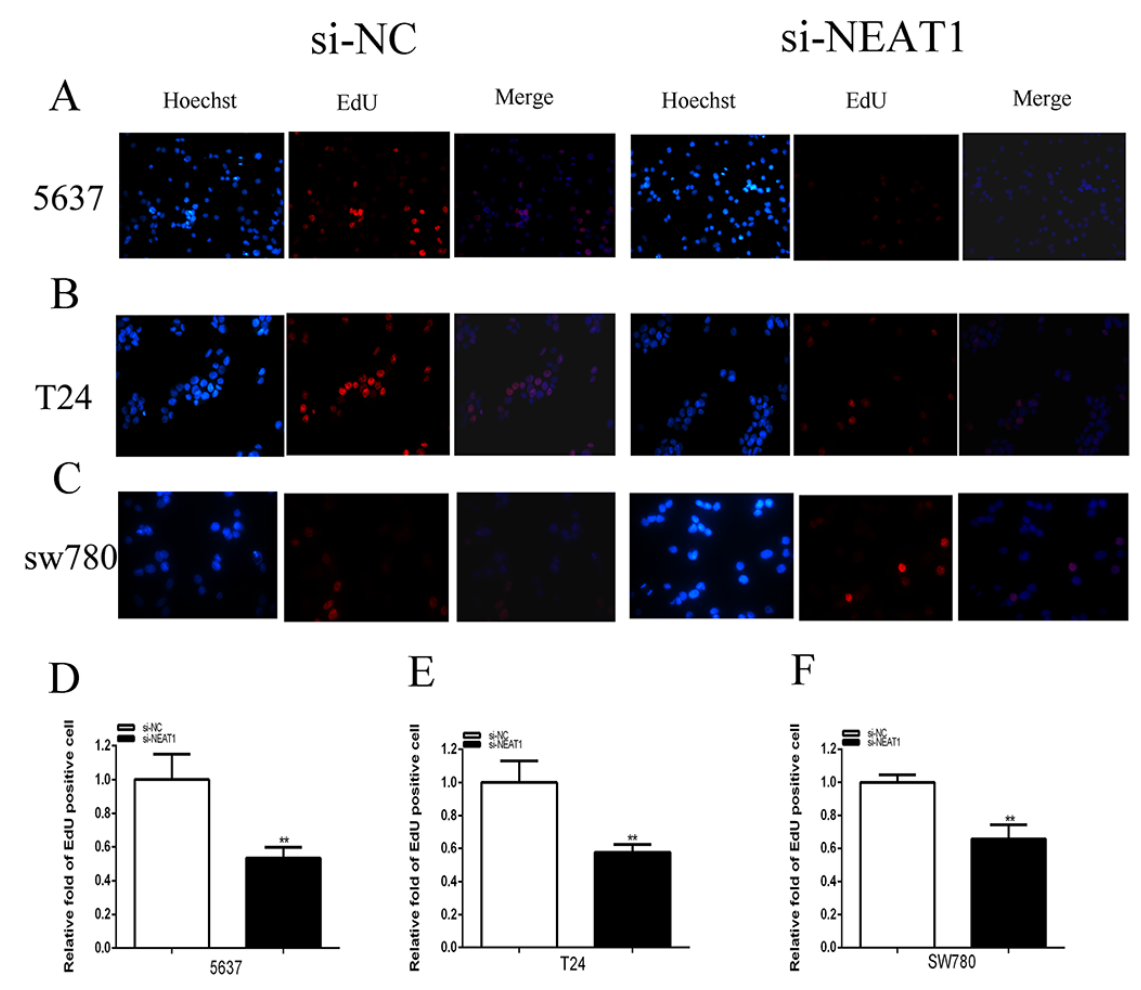

Figure 3: Silencing NEAT1 inhibited cell proliferation by EDU assay as well. Cell proliferation was detected by EDU assay. After transfection of si-NEAT1 or negative control si-NC, Pictures were taken from each well quickly using a digital camera system. Cell proliferation suppression was observed in bladder cancer 5637 cells A and D. T24 cells B and $\mathbf{E}$. and SW780 cells $\mathbf{C}$ and F. (p<0.01). Data are indicated as mean $\pm \mathrm{SD}(* * \mathrm{p}<0.01)$. 
A

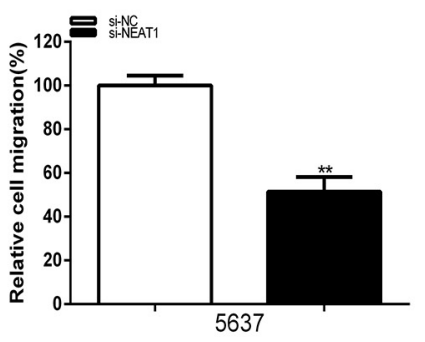

$\mathrm{B}$

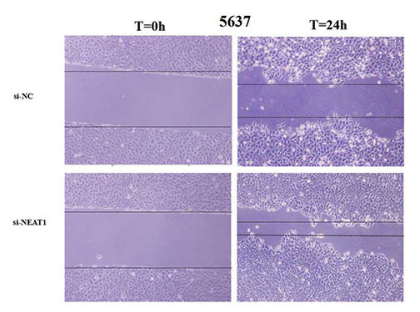

C

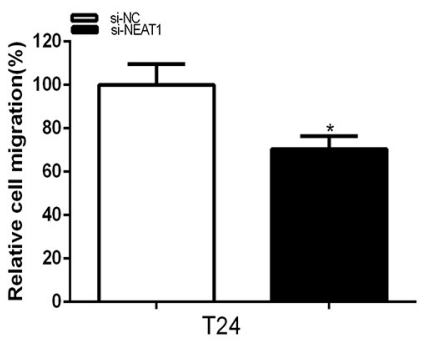

$\mathrm{D}$

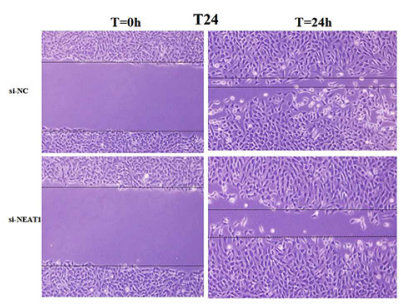

$\mathrm{E}$
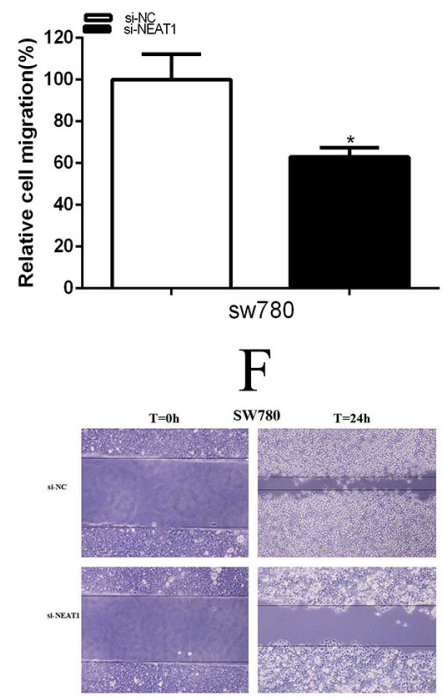

Figure 4: Silencing NEAT1 inhibited migration. The effects of si-NEAT1 on cell migration were observed in 5637 cells $\mathbf{D}$. (p<0.01), T24 cells E. $(p<0.05)$ and SW780 cells F. $(p<0.05)$. The relative rate of cell migration was calculated in T24 A. and 5637 B. cells. Data are shown as mean $\pm \mathrm{SD}(* \mathrm{p}<0.05, * * \mathrm{p}<0.01)$.

A
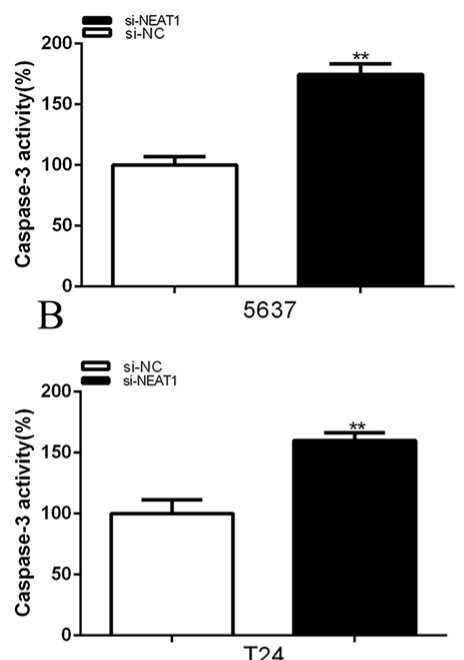

$\mathrm{C}$

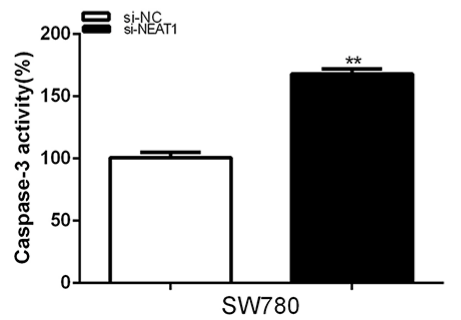

$\mathrm{D}$
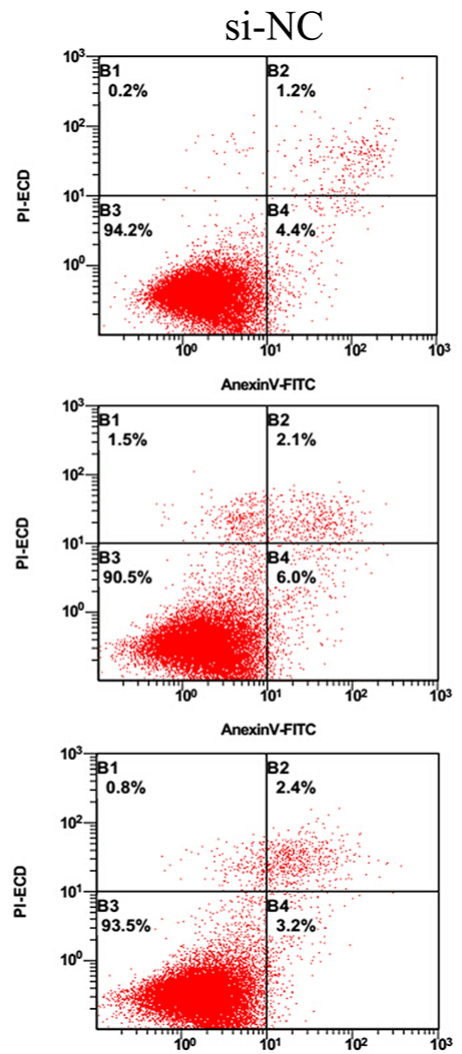
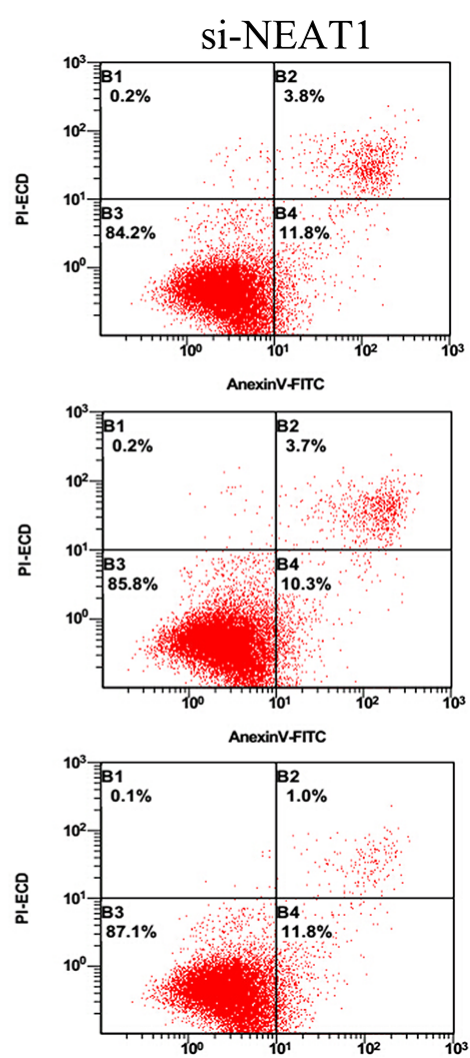

Figure 5: Silencing NEAT1 induced apoptosis. 48 hours after transfection of si-NEAT1 or negative control si-NC, the cell apoptosis changes were determined by ELISA assay and flow cytometry analysis. The relative activity of caspase- 3 was increased in 5637 cells A. T24 cells B. and SW780 cells C. $(\mathrm{p}<0.01)$ treated with si-NEAT1. Cell apoptosis induction were observed in 5637 cells (C),T24 cells D. and SW780 cells F. treated with si-NEAT1 or si-NC using flow cytometry analysis. Data are shown as mean \pm SD. $(* * p<0.01)$. 
as a required therapeutic method targeting for bladder cancer.

\section{MATERIALS AND METHODS}

\section{Patient and specimens}

All patients or family members signed the written informed consent. Fresh clinical bladder cancer specimens and adjacent normal tissues were collected from 65 patients who received radical cystectomy surgery from 2013 to 2015 in The First Affiliated Hospital of Anhui Medical University. All the fresh tissues were put into liquid nitrogen immediately after surgical removal, and then saved into $-80^{\circ} \mathrm{C}$ ultrafreezer for mRNA isolation. Patients with selective criteria were subsequently being exclusive of: Received other treatment before surgery including chemotherapy ect; Diagnosed as bladder benign tumors; Diagnosed as additional cancers; Refused consent. Clinicopathologic information and data of the remaining 65 patients were prospectively entered into the hospital database. The study was approved by The First Affiliated Hospital of Anhui Medical University.

\section{Cell Lines and Culture Conditions}

Human bladder cancer cell lines (Bladder cancer 5637, T24 and SW780 cells) were purchased from the Institute of Cell Biology, Chinese Academy of Sciences (Shanghai, China). T24 and SW780 cells were cultured at $37^{\circ} \mathrm{C}$ in a $\mathrm{CO} 2$ incubator in Dulbecco's modified Eagle's media (DMEM) (Invitrogen, Carlsbad, CA, USA) supplemented with $10 \%$ fetal bovine serum (FBS) and $1 \%$ penicillin-streptomycin. 5637 cell line was cultured in RPMI-1640 Medium (Invitrogen, Carlsbad, CA, USA) supplemented with $10 \%$ fetal bovine serum (FBS) and $1 \%$ penicillin-streptomycin. The SV-HUC-1 cells were cultured in F12K medium (Invirtogen, Carlsbad, CA, USA) supplemented with $10 \%$ fetal bovine serum (FBS) and $1 \%$ penicillin-streptomycin.

\section{siRNA transfection}

Cell Transfection GC cell lines were transfected with siRNA using Lipofectamine 2000 (Invitrogen, Carlsbad, CA, USA), according to the manufacture'sprotocol. NEAT1-specific siRNAs (si-NEAT1:Sense GAGGGAUGA GGGUGAAGAA and antisense UUCUUCACCCUCAU CCCUC and si-NEAT1(a): sense GGAGGAGUCAGG AGGAAUA and antisense UAUUCCUCCUGACUCCUCC and negative control siRNA (si-NC) were purchased from GenePharma, Shanghai, China.

\section{Real-time quantitative PCR}

Total RNA was extracted from the frozen tissues using TRIzol (Invitrogen, Grand Island, NY, USA) according to the manufacturer's instructions. RNA concentrations were estimated by spectrophotometer absorbance readings of $260 \mathrm{~nm}$. One microgram of total RNA was used to transcribe reversely to cDNA using a Reverse Transcription Kit (Takara, Dalian, China). ABI 7500 real-time PCR system (Applied Biosystems, Foster City, CA, USA) was used to quantify NEAT1. Ten microliters of SYBR Premix ExTaq (Takara, Dalian, China) for quantitative PCR (qPCR) was mixed according to the manufacturer's instructions. Primer sequences in our study were as follows [25]: NEAT1 sense, 5'-CTAGAGGCTCGCATTGTGTG-3' and reverse 5'-GCCCACACGAAACCTTACAT-3'. GAPDH sense, 5'-CGCTCTCTGCTCCTCCTGTTC-3' and reverse 5'-ATCCGTTGACTCCGACCTTCAC-3'. The relative expression was calculated using the equation: $\Delta_{\mathrm{Ct}}=$

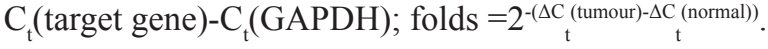

\section{MTT assay}

The bladder cancer cells proliferation was also measured by using 3-[4, 5-dimethylthiazol-2-yl]-2, 5-diphenyl-tetrazolium bromide (MTT) assay. Cells were grown in a 96-well plate for 24 hours, transfected with si-NEAT1 or negative control si-NC and incubated in normal medium. Cells were seeded in $0.1 \mathrm{mg} / \mathrm{ml}$ MTT for 4 hours and lysed in dimethyl sulfoxide (DMSO) at room temperature for 10 minutes. The absorbance in each well was detected by a microplate reader (Bio-Rad, Hercules, CA, USA) at 0, 24, 48 and $72 \mathrm{~h}$ after transfection.

\section{EdU assay}

5-ethynyl-20-deoxyuridine (EdU) assay kit (Ribobio, Guangzhou, China) was detected for cell proliferation according to the manufacturer's instructions. Pictures were taken from each well quickly using a digital camera system.

\section{Scratch assay}

Cell migration was detected by scratch assay following the introduction. 5637, T24 and SW780 cell lines were seeded in 6-well plate and cultured in incubator to get $100 \%$ gather before transfection. A sterile $200 \mu \mathrm{l}$ pipette tip was used to generate a clear line in the wells after cells were transfected with siRNAs or si-NC. Pictures were taken from each well quickly using a digital camera system. Migration distance was counted at the time of $0 \mathrm{~h}$ and $24 \mathrm{~h}$. 


\section{Caspase 3 ELISA assay}

Bladder cancer 5637, T24 and SW780 cells were transfected with si-NEAT1 or negative control si-NC. 48 hours after transfection, apoptosis induced by NEAT1 silencing was detected by calculating the activity of caspase 3 using the Caspase 3 ELISA assay kit (Hcusabio, Wuhan, China) according to the manufacturer's instructions. OD values were measured by using a microplate reader (Bio-Rad). Data were shown as the ratios between the OD values of si-NEAT1 transfected cells and those of negative control si-NC transfected cells.

\section{Flow cytometry analysis of cell apoptosis}

Cells were cultured in normal medium after transfection with NEAT1 or si-NC. 48 hours after transfection, cells were harvested and resuspended in fixation fluid. $5 \mu$ l Annexin V - FIFC and $2 \mu 1$ propidium iodide were added to $500 \mu \mathrm{l}$ cell suspension. Cell apoptosis was then determined by using flow cytometry (EPICS, XL-4, Beckman, CA, USA).

\section{Statistical analysis}

All experimental assays were performed in triplicate. The NEAT1 expression differing between bladder cancer tissues and matched normal tissue were analyzed using paired samples t-test. The differences between si-NEAT1 and si-NC transfected cells in the MTT assay were analyzed using ANOVA. Chi-square test was performed to explore the associations between NEAT1 expression and clinical characteristics. The independent samples t-test was used to analyze other data. All these statistical analyses were performed by using SPSS 16.0. $P$ value of less than 0.05 was considered to be statistically significant.

\section{ACKNOWLEDGMENTS}

The authors are indebted to the donors, whose names were not included in the author list, but who participated in this program. The work was supported by NSFC grant (NO:81370856, 81470986)

\section{CONFLICTS OF INTEREST}

The authors declare that they have no conflict of interest.

\section{REFERENCES}

1. Kang JJ, Steinberg ML, Kupelian P, Alexander S, King CR. Whole Versus Partial Bladder Radiation: Use of an Imageguided Hypofractionated IMRT Bladder-preservation
Protocol. Am J Clin Oncol. 2015. doi: 10.1097/ COC.0000000000000237.

2. Ecke TH. Biomarker in Cisplatin-Based Chemotherapy for Urinary Bladder Cancer. Adv Exp Med Biol. 2015; 867:293-316.

3. Von Schoen-Angerer T, Wilkens J, Kienle GS, Kiene H, Vagedes J. High-Dose Viscum album Extract Treatment in the Prevention of Recurrent Bladder Cancer: A Retrospective Case Series. Perm J.2015; 19:76-83.

4. Tan J, Sun C, Xu K, Wang C, Guo J. Immobilization of ALA- $\mathrm{Zn}^{\mathrm{II}}$ Coordination Polymer Pro-photosensitizers on Magnetite Colloidal Supraparticles for Target Photodynamic Therapy of Bladder Cancer. Small. 2015; 11:6338-46.

5. Chen M, Zhuang C, Liu Y, Li J, Dai F, Xia M, Zhan Y, Lin J, Chen Z, He A, Xu W, Zhao G, Guo Y, et al. Tetracyclineinducible shRNA targeting antisense long non-coding RNA HIF1A-AS2 represses the malignant phenotypes of bladder cancer. Cancer Letters. 2016. doi: 10.1016/j. canlet.2016.03.037.

6. Yao Y, Ma J, Xue Y, Wang P, Li Z, Liu J, Chen L, Xi Z, Teng H, Wang Z, Li Z, Liu Y. Knockdown of long noncoding RNA XIST exerts tumor-suppressive functions in human glioblastoma stem cells by up-regulating miR-152. Cancer Letters. 2015; 359:75-86.

7. Silva A, Bullock M, Calin G. The Clinical Relevance of Long Non-Coding RNAs in Cancer. Cancers (Basel). 2015; 7:2169-82.

8. Nie W, Ge HJ, Yang XQ, Sun X, Huang H, Tao X, Chen WS, Li B. LncRNA-UCA1 exerts oncogenic functions in non-small cell lung cancer by targeting miR-193a-3p. Cancer Letters. 2016; 371:99-106.

9. Li J, Zhuang C, Liu Y, Chen M, Zhou Q, Chen Z, He A, Zhao G, Guo Y, Wu H, Cai Z, Huang W. shRNA targeting long non-coding RNA CCAT2 controlled by tetracyclineinducible system inhibits progression of bladder cancer cells. Oncotarget. 2016. doi: 10.18632/oncotarget.8259.

10. Schmitt AM, Chang HY. Gene regulation: Long RNAs wire up cancer growth. Nature. 2013; 500:536-7.

11. Zheng S, Chen H, Wang Y, Gao W, Fu Z, Zhou Q, Jiang Y, Lin Q, Tan L, Ye H, Zhao X, Luo Y, Li G, et al. Long non-coding RNA LOC389641 promotes progression of pancreatic ductal adenocarcinoma and increases cell invasion by regulating E-cadherin in a TNFRSF10A-related manner. Cancer Letters. 2016; 371:354-65.

12. Wang D, Ding L, Wang L, Zhao Y, Sun Z, Karnes RJ, Zhang J, Huang H. LncRNA MALAT1 enhances oncogenic activities of EZH2 in castration-resistant prostate cancer. Oncotarget. 2015; 6:41045-55. doi: 10.18632/oncotarget.5728.

13. Wang J, Shao N, Ding X, Tan B, Song Q, Wang N, Jia Y, Ling $\mathrm{H}$, Cheng $\mathrm{Y}$. Crosstalk between transforming growth factor- $\beta$ signaling pathway and long non-coding RNAs in cancer. Cancer Letters. 2016; 370:296-301. 
14. Wang Q, Zhang J, Liu Y, Zhang W, Zhou J, Duan R, Pu P, Kang C, Han L. A novel cell cycle-associated lncRNA, HOXA11-AS, is transcribed from the 5-prime end of the HOXA transcript and is a biomarker of progression in glioma. Cancer Letters. 2016; 373:251-9.

15. Hu X, Bao J, Wang Z, Zhang Z, Gu P, Tao F, Cui D, Jiang W. The plasma lncRNA acting as fingerprint in nonsmall-cell lung cancer. Tumour Biol. 2015. doi: 10.1007/ s13277-015-4023-9.

16. Zhang Z, Zhou C, Chang Y, Zhang Z, Hu Y, Zhang F, Lu Y, Zheng L, Zhang W, Li X, Li X. Long non-coding RNA CASC11 interacts with hnRNP-K and activates the $\mathrm{WNT} / \beta$-catenin pathway to promote growth and metastasis in colorectal cancer. Cancer Letters. 2016. doi: 10.1016/j. canlet.2016.03.022.

17. Tseng YY, Moriarity BS, Gong W, Akiyama R, Tiwari A, Kawakami H, Ronning P, Reuland B, Guenther K, Beadnell TC, Essig J, Otto GM, O'Sullivan MG, et al. PVT1 dependence in cancer with MYC copy-number increase. Nature. 2014; 512:82-6.

18. Zhuang C, Li J, Liu Y, Chen M, Yuan J, Fu X, Zhan Y, Liu L, Lin J, Zhou Q, Xu W, Zhao G, Cai Z, et al. Tetracyclineinducible shRNA targeting long non-coding RNA PVT1 inhibits cell growth and induces apoptosis in bladder cancer cells. Oncotarget. 2015; 6:41194-203. doi: 10.18632/ oncotarget.5880.

19. Li Y, Li Y, Chen W, He F, Tan Z, Zheng J, Wang W, Zhao Q, Li J. NEAT expression is associated with tumor recurrence and unfavorable prognosis in colorectal cancer. Oncotarget. 2015; 6:27641-50. doi:10.18632/oncotarget.4737.

20. Guo S, Chen W, Luo Y, Ren F, Zhong T, Rong M, Dang Y, Feng Z, Chen G. Clinical implication of long non-coding RNA NEAT1 expression in hepatocellular carcinoma patients. Int J Clin Exp Pathol. 2015; 8:5395-402.

21. Pan LJ, Zhong TF, Tang RX, Li P, Dang YW, Huang SN, Chen G. Upregulation and clinicopathological significance of long non-coding NEAT1 RNA in NSCLC tissues. Asian Pac J Cancer Prev. 2015;16:2851-5.

22. Chakravarty D,Sboner A, Nair SS, Giannopoulou E, Li R, Hennig S, Mosquera JM, Pauwels J, Park K, Kossai M, MacDonald TY, Fontugne J, Erho N, et al. The oestrogen receptor alpha-regulated lncRNA NEAT1 is a critical modulator of prostate cancer. Nat Commun. 2014; 5:5383.

23. Blume CJ, Hotz-Wagenblatt A, Hüllein J, Sellner L, Jethwa A, Stolz T, Slabicki M, Lee K, Sharathchandra A, Benner A, Dietrich S, Oakes CC, Dreger P, et al. p53-dependent non-coding RNA networks in chronic lymphocytic leukemia. Leukemia. 2015; 29:2015-23.

24. You J, Zhang Y, Liu B, Li Y, Fang N, Zu L, Li X, Zhou Q. MicroRNA-449a inhibits cell growth in lung cancer and regulates long noncoding RNA nuclear enriched abundant transcript 1. Indian J Cancer. 2014; 51 Suppl 3:e77-81.

25. Choudhry H, Albukhari A, Morotti M, Haider S, Moralli D, Smythies J, Schödel J, Green CM, Camps C, Buffa F,
Ratcliffe P, Ragoussis J, Harris AL, et al. Tumor hypoxia induces nuclear paraspeckle formation through HIF- $2 \alpha$ dependent transcriptional activation of NEAT1 leading to cancer cell survival. Oncogene. 2015; 34:4546.

26. Zhen L, Yun-Hui L, Hong-Yu D, Jun M, Yi-Long Y. Long noncoding RNA NEAT1 promotes glioma pathogenesis by regulating miR-449b-5p/c-Met axis. Tumour Biol. 2015 Aug 5.

27. Gernapudi R, Wolfson B, Zhang Y, Yao Y, Yang P, Asahara H, Zhou Q. miR-140 Promotes Expression of long non-coding RNA NEAT1 in Adipogenesis. Mol Cell Biol. 2015; 36:30-8.

28. Cooper DR,Carter G,Li P,Patel R,Watson JE,Patel NA. Long Non-Coding RNA NEAT1 Associates with SRp40 to Temporally Regulate PPAR $\gamma 2$ Splicing during Adipogenesis in 3T3-L1 Cells. Genes (Basel). 2014; 5:1050-63.

29. Aune TM, Crooke PS 3rd, Spurlock CF 3rd. Long noncoding RNAs in $\mathrm{T}$ lymphocytes. J Leukoc Biol. 2016;99:31-44

30. Zhang H, Zhu C, Zhao Y, Li M, Wu L, Yang X, Wan X, Wang A, Zhang MQ, Sang X, Zhao H. Long non-coding RNA expression profiles of hepatitis Cvirus-related dysplasia and hepatocellular carcinoma. Oncotarget. 2015; 6:43770-8. doi: 10.18632/oncotarget.6087.

31. Lu Z, Xiao Z, Liu F, Cui M, Li W, Yang Z, Li J, Ye L, Zhang X. Long non-coding RNA HULC promotes tumor angiogenesis in liver cancer by up-regulating sphingosine kinase 1 (SPHK1). Oncotarget. 2016; 7:241-54. doi: 10.18632/oncotarget.6280.

32. Ji J, Tang J, Deng L, Xie Y, Jiang R, Li G, Sun B. LINC00152 promotes proliferation in hepatocellular carcinoma by targeting EpCAM via the mTOR signaling pathway. Oncotarget. 2015; 6:42813-24. doi: 10.18632/oncotarget.5970.

33. Yang L, Qiu M, Xu Y, Wang J, Zheng Y, Li M, Xu L, Yin R. Upregulation of long non-coding RNA PRNCR1 in colorectal cancer promotes cell proliferation and cell cycle progression. Oncol Rep. Oncol Rep. 2016; 35:318-24.

34. Jang W, Liu Y, Liu R, Zhang K, Zhang Y. The IncRNA DEANR1 facilitates human endoderm differentiation by activating FOXA2 expression. Cell Rep. 2015 ;11:137-48

35. Li HJ, Li X, Pang H, Pan JJ, Xie XJ, Chen W. Long noncoding RNA UCA1 promotes glutamine metabolism by targeting miR-16 in human bladder cancer. Jpn J Clin Oncol. 2015; 45:1055-63.

36. Li S, Yu Z, Chen SS, Li F, Lei CY, Chen XX, Bao JM, Luo Y, Lin GZ, Pang SY, Tan WL. The YAP1 oncogene contributes to bladder cancer cell proliferation and migration by regulating the $\mathrm{H} 19$ long noncoding RNA. Urol Oncol. 2015; 33:427.e1-427.e10.

37. Zhao XL, Zhao ZH, Xu WC, Hou JQ, Du XY. Increased expression of SPRY4-IT1 predicts poor prognosis and promotes tumor growth and metastasis in bladder cancer. Int J Clin Exp Pathol. 2015; 8:1954-60.

38. Xue Y, Ma G, Zhang Z, Hua Q, Chu H, Tong N, Yuan L, Qin $\mathrm{C}$, Yin $\mathrm{C}$, Zhang Z, Wang M. A novel antisense long noncoding 
RNA regulates the expression of MDC1 in bladder cancer. Oncotarget. 2015; 6:484-93. doi: 10.18632/oncotarget.2861.

39. Wu Y, Yang L, Zhao J, Li C, Nie J, Liu F, Zhuo C, Zheng Y, Li B, Wang Z, Xu Y. Nuclear-enriched abundant transcript 1 as a diagnostic and prognostic biomarker in colorectal cancer. Mol Cancer. 2015; 14:191. doi: 10.1186/ s12943-015-0455-5.

40. He C, Jiang B, Ma J, Li Q. Aberrant NEAT1 expression is associated with clinical outcome in high grade glioma patients. APMIS. 2016; 124:169-74.

41. Lu Y, Li T, Wei G, Liu L, Chen Q, Xu L, Zhang K, Zeng $\mathrm{D}$, Liao R. The long non-coding RNA NEAT1 regulates epithelial to mesenchymal transition and radioresistance in through miR-204/ZEB1 axis in nasopharyngeal carcinoma. Tumour Biol. 2016. doi: 10.1007/s13277-015-4773-4.

42. Lennox KA, Behlke MA. Cellular localization of long noncoding RNAs affects silencing by RNAi more than by antisense oligonucleotides. Nucleic Acids Res. 2016; 44:863-77.

43. Hirose T, Virnicchi G, Tanigawa A, Naganuma T, Li R, Kimura $\mathrm{H}$, et al. NEAT1 long noncoding RNA regulates transcription via protein sequestration within subnuclear bodies. Mol Biol Cell. 2014; 25:169-83.
44. Datta J, Smith A, Lang JC, Islam M, Dutt D, Teknos TN, et al. microRNA-107 functions as a candidate tumorsuppressor gene in head and neck squamous cell carcinoma by downregulation of protein kinase Cvarepsilon. Oncogene. 2012; 31:4045-53.

45. Poomsawat S, Sanguansin S, Punyasingh J, Vejchapipat $P$, Punyarit P. Expression of cdk6 in head and neck squamous cell carcinoma. Clin Oral Investig. 2016; 20:57-63.

46. Wang P, Wu T, Zhou H, Jin Q, He G, Yu H, Xuan L, Wang X, Tian L, Sun Y, Liu M, Qu L. Long noncoding RNA NEAT1 promotes laryngeal squamous cell cancer through regulating miR-107/CDK6 pathway. J Exp Clin Cancer Res. 2016;35:22.

47. Liu L, Liu Y, Zhuang C, Xu W, Fu X, Lv Z, Wu H, Mou L, Zhao G, Cai Z, Huang W. Inducing cell growth arrest and apoptosis by silencing long non-coding RNA PCAT-1 in human bladder cancer. Tumour Biol. 2015;36:7685-9.

48. Pan LJ, Zhong TF, Tang RX, Li P, Dang YW, Huang SN, Chen G. Upregulation and clinicopathological significance of long non-coding NEAT1 RNA in NSCLC tissues. Asian Pac J Cancer Prev. 2015;16:2851-5 